Fall 2018

\title{
Review: Peace Weavers: Uniting the Salish Coast through Cross-Cultural Marriages by Candace Wellman
}

Chris Friday

Western Washington University, chris.friday@wwu.edu

Follow this and additional works at: https://cedar.wwu.edu/history_facpubs

Part of the United States History Commons, and the Women's History Commons

\section{Recommended Citation}

Chris Friday (2018) Review: Peace Weavers: Uniting the Salish Coast through Cross-Cultural Marriages by Candace Wellman. Pacific Historical Review: Vol. 87 No. 4, Fall 2018, pp. 719-721 DOI: 10.1525/phr.2018.87.4.719

This Book Review is brought to you for free and open access by the History at Western CEDAR. It has been accepted for inclusion in History Faculty and Staff Publications by an authorized administrator of Western CEDAR. For more information, please contact westerncedar@wwu.edu. 
forth in time to historicize the conditions under which government officials set in motion policies and commissions to reduce Indian-held lands. The first three chapters examine how government agents used the discourse of blood to distinguish between "real" Indians, "competent" Indians, and "other unrecognized” Indians. Chapter 4 offers a well-crafted and nuanced analysis of the failure of the Indian New Deal to bring justice to the unrecognized Native Americans of mixed descent. Her final chapter takes us into a more racially obsessed state where the "one-drop rule" of African American ancestry was all it took to de-authenticate Virginia Indians of their Indianness. For the sake of contrast, the author concludes her book with a brief discussion about the eastern Cherokees' use of blood quantum rhetoric to reclaim their Indian authenticity and sovereignty in North Carolina.

Some readers will find Ellinghaus's arguments very satisfying; others will question the portability of the book's methods and the lack of balance between different case studies. Individual cases, for example, are given thorough analysis, while state Indians such as the Seminole in Oklahoma and the Rappahannocks, Pamunkeys, Monacans, and Mattaponis in Virginia, are often dealt with in generalizations that lack detail. Notwithstanding, these shortcomings do not detract from the avid novelty of Ellinghaus's arguments and the way that she vividly brings forth a nuanced reading of the archives to unpack the intricate colonial dynamics between the blood quantum narrative, the assimilation policy, and the settler colonial polyvalent mobility. Blood Will Tell makes a brilliant and original contribution to historical scholarship on Indians, race, and settler colonialism in western American history and merits a wide readership.

University of Nebraska-Lincoln

BALIGH BEN TALEB

\section{Peace Weavers: Uniting the Salish Coast through Cross-Cultural Marriages.} By Candace Wellman. (Pullman, Washington State University Press, 2017. xii +280 pp.)

Independent historian Candace Wellman spent nearly two decades painstakingly combing local sources regarding "cross-cultural" households created by the unions between Coast Salish women and American men in the northern Puget Sound between the I850s and I870s. Out of more than a hundred such cases for which she has data, Wellman focuses on four couples arguing that the "Indigenous wives occupied a middle ground between people of alien 
cultures" and successfully blended cultures (p. II). She also contends that the women and their descendants contributed significantly to the social and political successes of tribal communities in the region.

What eventually became San Juan, Whatcom, and Skagit Counties in Washington proved to be a good location to study "clusters" of interracial households prior to the establishment of a full-fledged settler colonialism. Wellman's estimates for the region suggest that in I860 some 80 to 90 percent of "married" couples were interracial and even as late as 1870 the proportion stood at perhaps two-thirds. During this time span, these regions of Washington remained outside the main thrust of settler colonialism, and interracial households emerged around key transportation and trade centers along with a few fledgling industrial sites-coal mines, water-powered sawmills, and lime kilns—-that neighbored established Coast Salish communities. Wellman rightly argues that the women's marriages, customary or not, to American men were often perceived within the women's families as diplomatic alliances wherein Coast Salish family heads expected the new in-law to bring social prestige, trade, and political connections. For their part, American men's motives were, according to Wellman, about access to trade networks, domestic labor, land claims, companionship, and sex. The relationships varied considerably. Some were loving and lasting, others contentious, violent, and short. Most of the wives outlasted or outlived their husbands and remained connected to their Indigenous families, ultimately living on or near reservations.

Wellman's study demonstrates that no "metis" community emerged. Instead, the children of these marriages found no place in the emergent settler society that ostracized their parents and them as racialized "others." The women, their children, and sometimes grandchildren often sought to maintain some connection to tribal communities. Some were able to merge back into reservations, some remained outside the reservations but continued to push for tribal rights, and still others remained marginalized socially and politically. Depending on one's focus, the legacy can be read as triumphant, marginal, or disturbing. Wellman chose the first.

Wellman's study is at its best in the detailed tracing of individual lives and relationships. Readers may find the constant switching between wives, husbands, and descendants dizzying, but Wellman works hard to maintain the narrative thread. What remains difficult to determine are motivations and expectation of the many different individuals; and Wellman, despite a pledge and a valiant effort not to, at times imposes her contemporary 
assumptions and thinking. That cavil aside, Wellman adds significant detail that will be worth carefully mining, should scholars wish to investigate multiracial relationships on the eve of, and in the early years of, settler colonialism.

Western Washington University

CHRIS FRIDAY

Spirit in the Rock: The Fierce Battle for Modoc Homelands. By Jim Compton. (Pullman, Washington State University Press, 2017. xxii + 318 pp.)

"If the historian's role is to sift details for the themes," journalist Jim Compton writes, "the journalist's job is to 'parachute in,' find a story line in the tangle of facts, and enliven the narrative with memorable personalities" (p. xv). Compton's posthumously published book is a well-sourced account of the Modoc War, which took place on the Oregon-California border in the early I870s. While it leaves much of the contextual framing to historian Boyd Cothran's afterword, the book provides a nuanced case study whose "memorable personalities" and richly detailed prose illuminate the complexities of American settler colonialism.

Comprised of thirty-seven page-turning chapters, the narrative is divided into three sections which cover treaty negotiations, removal of the Modoc to the Klamath Reservation, and their subsequent departure; the beginning of armed conflict and a six-week stalemate when the Modoc retreated to area lava beds; and the eventual routing of Modoc men, women, and children from their stronghold, their capture by the Army, and the trial and execution of four Modoc men, including Captain Jack. Compton evokes the dramatic environmental setting of the lava beds and the challenges that soldiers and the Modoc families faced in the protracted conflict.

At its core, Compton's book is about both the limits of peacemaking, and the federal negligence and willful ignorance that led to violence amidst the heightened tension of American resettlement. Modoc families fled Oregon's Klamath Reservation, hoping to secure their own reserve, which many officials recommended. But when a faction led by Hooker Jim attacked and killed several settlers, white sympathy eroded and the Army sought to capture the families, a nearly impossible task given their escape into the lava beds. Internal divisions within the Modoc led to an attack on a peace commission during which Captain Jack killed General Edward Canby. The military regrouped, eventually capturing Captain Jack and his followers with the aid 